\title{
The Relationship between Ethical Justice \& Practical Wisdom: Aristotle's and Ghazali's Viewpoints
}

\author{
Marieh Seyyed Ghoreyshi ${ }^{1}$, Ibrahim Nazhat ${ }^{2}$, Ghodratallah Rezaee ${ }^{3}$ \\ ${ }^{1}$ Assistant Professor - University of Tehran \\ ${ }^{2}$ Assistant Professor - University of Tehran \\ ${ }^{3} \mathrm{PhD}$ student in Education Teaching - University of Tehran
}

\begin{abstract}
The theory of justice is one of crucial principles of philosophical and rational principles in all Greek philosophical schools and then in Islamic morality and ethics. A large number of morality philosophers and exegetes use different concepts of justice interchangeably. They do not make any distinction between justice as a perfect virtue and justice as a component of virtues because they mix the true mediocrity with mediocrity of actions. Aristotle and Ghazali are of philosophers who concentrated on this crucial mixture. This study initially analyzes Aristotle's and Ghazali's mediocrity. Then, it highlights the practical wisdom status and examines justice as a perfect virtue from these scholars' viewpoints. Finally, ethical justice and practical wisdom identicality is evaluated.
\end{abstract}

Keywords: Justice, practical wisdom, virtue, mediocrity, Aristotle, Ghazali. 


\section{The Study Significance:}

Justice is one of essentially crucial concepts for personal and cumulative prosperity. It is one of the most fundamental concepts in intellectual and philosophical ethics. Most ethics theories and schools attempt to examine this concept theoretically and practically and attribute themselves to it. Equality theories are observed in nearly all Greek philosophical schools and then in Islamic ethics philosophies. A large number of Islamic scientists accept this viewpoint by doing different analyses. Concept of equality conveys particular complexity. Accordingly, some ethics philosophers and their exegetes mix different concepts of equality: Equality as the true mediocrity and equality as a practical rule \& equality as a universal virtuosity and equality as some components of virtues. These mixtures are required to be accounted for properly. As ethics and morality systems are initially explained by accounting for the related concepts accurately, this study attempts to examine Aristotelian virtue ethics and mediocrity and Ghazali's and Aristotle's practical wisdom, given that the true mediocrity differs from mediocrity of actions. Also, Ghazali's and Aristotle's equality and practical wisdom are evaluated. Specifically, a comparison is made between equality as a universal virtue and equality as a social performance by studying Aristotle's Nicomachus and Ghazali's Thyâ' 'ulūm al-dīn andMizanal-amal.

\section{Aristotle's the theory of justice:}

As the virtue concept is directly interrelated with this theory properties and Aristotle defines morality in terms of virtuosity (Crisp, p.622), this study initially analyzes this concept. Aristotle describes virtuosity as follows: A mediocre choice criterion in accordance with wisdom or scholars' discretion (Aristotle, 1999: 1107a). He introduces habit and mediocre for referring to unclear essence of virtue (the ambiguous nature) and its typology (the acquired nature). Aristotle believes that virtue is derived from habits. There are three components in self: emotions (passions), powers (talents), and habits. The virtue is inevitably derived from one of these components; nevertheless, Aristotle's assumption underpins that virtues and villainess are not likely based on passions and powers as regards ambiguous nature (ibid: 1106a). Accordingly, virtues and villainess are habits which are in turn sustainable manners of human self and are resulted from accurate and moderate conducts. Aristotle inserts that no person is the holder of a virtue by doing it. Rather, that person should display behavior patterns in compliance with the virtue.

After the virtue nature is highlighted in terms of nature, one question should be answered: What a type of habits are virtues? As Aristotle points out, the virtue is in mediocre level. Macintyre (1988:65), one of Western exegesis of Aristotle ethics accepts that mediocrity is the only difficult concept of ethics. What does Aristotle mean by mediocrity? He introduces two types of mediocrity: Mediocrity as a truly virtue and mediocrity as a practical rule.

\section{The True Mediocrity:}

Prior to the analysis of this issue, virtue typology is divided as follows in accordance with Aristotle's division of human power. Accordingly, virtues are divided into intellectual virtues and ethical virtues. Humans have two powers: (1) Power of reason (orator), and (2) power of non-reason (nonorator). The latter has two dimensions: (I) vegetal self and animal self including wills and desires i.e. lusts and wrath. The vegetal self has no shared property with intellectual dimension. Animal self is associated with power of reason. He hears ration rule and observes it. Oratory virtues are called intellectual virtues, including speculative wisdom and practical wisdom. The nonoratory power such as braveness, modesty, generosity, etc. is known as ethical virtue (Aristotle, 1999: 1103a) 
The most excellent intellectual virtue is speculative wisdom, which occurs in the reflection life. The other intellectual virtue is practical wisdom, which makes contribution to accurate decisions in cases of varied minor behaviors. This virtue is the ultimate perfection of the practical wisdom (ibid: $1140 b)$.

According to Aristotle, virtues are clear mediocre choice habits, which are determined at the discretion of mind (bid: 1107a), because the practical wisdom determines the mediocrity and makes distinctions between virtues and villainess. The mediocrity is sometimes determined by the subject i.e. an informed practical person and sometimes by practical sages.

In accordance with Aristotle's definition of virtue, the virtue is based on the practical wisdom and is a type of mediocrity in terms of essence and nature. In the other words, it is always affected by an intermediate level and can precisely identify our mediocrity in varied minor cases and choose an adequately mediocre behavior. Therefore, it is important to reach a mediocre level and identify adequately mediocre behavior patterns, no matter whether we ourselves possess this practical wisdom or imitate practical sages.

As Aristotle points out, virtue (i.e. practical wisdom) is a key factor for integrating intellectual virtues with ethical ones. Human action is not completed unless practical reason is associated with ethical virtues (ibid: 1144b). Thus, ethical virtue is not the only determinant of human prosperity. The practical wisdom should also be taken into consideration for identifying properly virtuous conducts in varied minor cases. Aristotle views the practical sage as a moderate human who possesses an integrated virtue called practical wisdom, apparently or not. This virtue contains all other virtues (ibid: 1145a). This person can discern braveness, generosity, virtuosity, etc. in varied cases without any thought. This person enjoys all virtues and is a manifestation of mediocrity.
Accordingly, the virtue is a true mediocrity for reaching practical wisdom level without any extremes. It is a sensual perfection, which is created in humans as a subsidiary nature. This concept of mediocrity is an absolute virtue and a firm perfection. Therefore, the practical wisdom is a true mediocrity in terms of acquired essence. One question arises here: How can humans determine their ethical and moral behavior in varied conditions for reaching ethical virtues and perfect virtues (i.e. practical wisdom) without any practical wisdom and an awareness of equality? Aristotle attempts to introduce a method for determining virtues and villainess in actions and emotions by describing a proper mediocre rational rule.

\section{Mediocrity as a Practical Rule:}

Since ethical virtues are associated with actions and emotions, which in turn contain three manners i.e. the highest extreme, the lowest extreme, and mediocrity, the virtue is gained in a mediocre level. Aristotle believes that any value for helping humans gain prosperity is transformed into anti-value by following extremes. The mediocrity avoids removal of these values and virtues (ibid: $1106 \mathrm{~b})$. This mediocrity is defined in terms of humans rather than objects. In the other words, this mediocrity is described in a relationship with us (ibid.). Accordingly, Aristotle's mediocrity is much similar to the proportionality rather than identicality. It is not equal to the geometric intermediate point between segments or the mathematical mean of two numbers. The extremes are discerned by the mind without any standardization. For instance, somebody may be regarded as talkative by speaking during 2 minutes while the other person may be viewed a moderate speaker in a 10-hour dialogue. This similarly occurs for actions and reactions. For example, braveness is viewed as a mediocrity between cowardice (the highest level of fear) and temerity (the lowest level of fear). This does not mean that braveness is exactly between these two extremes. Rather, braveness can lies in cowardice and temerity. Mediocrity is 
gained by avoiding the extremes which are regarded villainess (ibid: 1106b). As Aristotle suggests the brave person should feel a sense of fear if necessary and should not feel a sense of fear if necessary. This is the braveness mediocrity. Accordingly, mediocre actions and reactions are feelings or actions which occur timely for the appropriate persons, in appropriate cases, and in an appropriate scale with adequate ways and means. Otherwise, villainess is caused and the extremes are involved (Seyyed Ghoreyshi, 2011:125).

\section{Equality:}

Same as mediocrity, Aristotle divides his equality theory into two categories: Equality as a true mediocrity and equality as a practical rule. The latter is primarily discussed by this scholar. Equality has two meanings: a general meaning and a specific meaning. The former is related to the real mediocrity without any extremes while the latter accompanies with the extremes. This section accounts for these equality types:

\section{Equality as a True Mediocrity:}

Equality as self virtue which is called a general meaning of equality involves all virtues. Aristotle believes: Equality as a general meaning is the ethical virtue and inequality is the ethical villainess. In the other words, equality generally involves all virtues because any person disregarding mediocrity and committing villainess does inequality (Aristotle, 1999: 1129b). Accordingly, Aristotle is likely expected to describe equality same as other virtues i.e. to determine two extremes of equality. He, conversely, does not define equality as self virtue as such. The equality is the true mediocrity without any extremes. It is a sensual perfection and virtue, which is created in humans as a subsidiary nature. Equality is not same as other virtues and any deviation is extremes. Both extremes are inequality properties while two sides of other virtues are not indications of villainess (ibid.).
As Aristotle points out, equality occurs when the ultimate target is prosperity. As all ethical virtues tend to reach prosperity, all related behaviors are viewed as equality (ibid: 1133a). Therefore, when wisdom, braveness, and modesty are discussed for oration, wrath, and passion, the fourth virtue is created by making a balance between the triple powers: Equality. Aristotle regards the general virtue of equality as a perfect virtue and calls it mother of virtues. Equality is the whole virtue rather than a component of it because equality involves all virtues. Consequently, the equality virtue is the true mediocrity.

With regard to Aristotle description of the justice virtue as a true mediocrity and his definition of practical wisdom virtue, humans possessing practical wisdom are indicators of equality and can discern varied ethical behaviors at their best within the most moderate framework without any reflection. This is equality status.

\section{Justice as a Practical Rule:}

The specific equality (the opposite of general equality) is a part of virtue. Aristotle uses this equality as a practical rule and divides it into two categories: Distributive equality \& remedial justice. The former is defined as the distribution of social careers, governance status, wealth, and other privileges among the public in accordance with meritocracy (ibid: 1134a). The main determinant of meritocracy in Aristotle Utopia, as Macintyre points out, is virtues. Accordingly, the relationship between equality and virtues is highlighted (Shahriyari, 2006: 91). Conversely, Plato offers a definition of self equality in The Republic, which is measured by equality in society (Plato, p. 300). In this viewpoint, there is not equality in personal terms. When equality concept is associated with an individual, his relationship with others is examined (Raphael, 1971: 117). According to Aristotle viewpoint, the main rule is not equality i.e. no rule and regulation focuses on identicality. Rather, in case of nonawareness about effective differences, individuals should be regarded identical. 
Works should comply with tasks and salaries. The equality is a mediocrity between cruelty infliction and cruelty sufferance in order to avoid each of these extremes in case of profitgaining (Aristotle, 1979: 1138b). The remedial justice is described as equality of citizens in human rights and generosity. The meritocracy is not involved in this justice (ibid: 1134b). The distributive justice involves shared property and always act in accordance with the geometric proportion while the remedial justice is primarily created in human relations and transactions and act in accordance with the numerical proportion. In the latter, the parties are judged equally in the courts and a numerical mediocrity is found accordingly. The greater the mistake enhances profitability for the offender, the greater it causes losses for him. Therefore, when the cruelty is intended to be determined, the term gain and loss is used. Equality is the mediocrity between more or less. More or less gain and loss have two opposite meanings: Gain as greater benefit and lower level of evil. Therefore, the remedial justice is the mediocrity between gain and loss (ibid.).

\section{Ghazali's Ethical Justice:}

Ghazali, inspired by Aristotle, views the virtue the mediocrity in terms of nature and typology. This scholar introduces the virtue as good manner (Ghazali, 1048: 49). He defines good manner as follows: The good manner is a firm framework in the self, which is actualized feasibly and immediately. In the case that the framework is rationally and conventionally acceptable, it is called the virtue. Otherwise, it is described as villainess (ibid: 12).

Ghazali defines 3 origins for this queen:

1- God creates good habits inside humans due to His kindness and blessing i.e. they are created as a good temperament;

2- Humans do virtuous actions by facing difficulties in a way that they are inherited and actualized without any reflection; and
3- Humans should interact with virtuous people in a way that good traits are inherited (Ghazali, 1996).

Aristotle's mediocrity theory is significantly accepted by Ghazali and other Islamic scholars such as Farabi (1992: 10-11), Ibn-Sina (1939:119, Fakhr Razi (1964: 385), Ameri (1029: 10-11), Sadrol Motaehelin, (1981:115), Allameh Tabatabaee (2012: 558-559), etc. They accepte his theory but interpret it differently. Therefore, mediocrity in Ghazali' theory is of great significance. In his view, although virtues are large in number, they are grouped under 4 categories: Wisdom, braveness, modesty, and justice. These categories are derived from 4 powers: ration, wrath, and passion. Any improvement in these powers means that the extremes are avoided and the mediocrity is dominant. Humans' mediocre powers revive the self-accuracy. Otherwise, the prosperity is not gained (Ghazali, 1030: 47).

\section{The True mediocrity:}

Ghazali divides virtues into two categories: Intellectual virtues \& ethical virtues. In the former, humans make a distinction between prosperity and villainy and follow the prosperity path in compliance with firm reasoning rather than weak imitation and vain images. The latter remove the extremes as impurity (ibid: 89). Rational virtues including speculative wisdom and practical wisdom are two virtues of rational power. Ghazali defines two components for rational power:

(1) The theoretical ration: It receives the essentially general theoretical facts from the rationpower. This category of facts is permanently true and its related virtue is the speculative wisdom; and

(2) The practical ration: it is associated with the body and its management. It is the source of human movement towards certain minor actions, which is done by thinking thoughts. This ration virtue is called temperament wisdom and is defined as follows: Temperament wisdom is the manner and 
virtue in the rational self, by which it can manage wrath and passion and determines their directions. This wisdom is a discretion of correct actions (ibid: 99).

Ghazali (1048:12) suggests that if the practical ration controls the body power, humans are forced to follow virtues. Accordingly, the virtue is a certain mediocre choice habit, which is determined by the wisdom since this practical ration determines the mediocrity and makes distinctions between virtue and villainess. As Ghazali defines, the virtue is the same as the practical wisdom and is viewed as the true mediocrity. To put it differently, in varied minor cases, it identifies the mediocrity precisely and chooses an accurately moderate behavior without any extremes. It is an absolute virtue and a firm perfection of self. Accordingly, the practical wisdom is a virtue, which integrates rational virtues with ethical virtues. The practical ration is added to the moral virtue for determining proper behaviors leading to ethical virtues in varied minor cases.

Ghazali's discretion of the true mediocrity is consistent with Aristotle's one. Same as Aristotle views the practical wisdom possessor (whether the person himself is the practical wisdom sage or imitates the practical sage) as the true mediocrity, Ghazali concentrates on ration and the Sharia sage as the most complete indicators of practical wisdom. Ghazali writes: It is difficult to discern the mediocrity. The true mediocrity is thinner than hair and sharper than sword. A small number of people are directed towards this mediocrity. Therefore, humans should assist God (Ghazali, 1991: 69). The practical wisdom possessor discerns all virtuous behaviors in varied cases. This person possesses all virtues and is a determinant of mediocrity.

\section{Justice as The True Mediocrity:}

Justice as the self-virtue involves all virtues in Ghazali's speech. There are 4 virtues on the basis of humans' different powers. The corrected ration makes contribution to the wisdom virtue. The corrected wrath leads to the braveness and the passion is resulted in modesty. Whenever passion and wrath are affected and improved by rational and Sharia power, the justice is formed. Therefore, justice is a manner for the triple power, which enjoys its own arrangements within a system (Ghazali, 1030:74).

Ghazali's definition of justice suggests that the above-mentioned powers should follow each other rules and observe the related arrangements. Wrath and passion should be subject to the ration power. Justice as a true mediocrity involves all virtues without any extremes. In this discussion, as initially mentioned in this paper, Ghazali gain awareness of this mixture. Significantly, Ghazali believes no extremity in case of justice and only defines one villainess against it: The cruelty. Passion and wrath observes ration rules without any mediocracy. In the other words, the wrath and the passion either follows ration rules or does not observe them. The latter cause cruelty. Accordingly, extremity is not observed in the justice virtue.

Although other Islamic scholars define the justice same as Ghazali, they cover two extremes: Cruelty and the submissiveness. The former is the highest level of justice extremity, which is described as the infringement of others' rules. The latter is the lowest level of justice extremity and is described as follows: The concerned human allows others to infringe his rights (Ibn Maskooyeh, 1033, as cited in Khajeh Nasir Toosi, 2008: 119). These scholars' viewpoints have two problems: (1) They attributed extremity to the justice concept; and (2) cruelty and the submissiveness i.e. two sociological concepts are viewed as two extremes of justice as a sensual concept.

As Ghazali suggests, the justice is a concept and a fact, whose impacts upon the society's transactions, judgements, and political affairs are observable after it is actualized. Whenever this virtue is actualized, it is observed in all matters of concern including transaction and policy (Ghazali, 1030: 104). As Ghazali 
considers the justice virtue as the true mediocrity which is interrelated with the practical wisdom, the practical wisdom possessor is the justice possessor.

As a result, Ghazali completely understands and accepts Aristotle's mediocrity rule. $\mathrm{He}$ is the first Islamic ethics philosopher who offers reasons for Aristotle's mediocrity. His prior colleagues including Farabi, Yahya Ibn-Adi, Abol Hassan Ameri, and Ibn-Sina do not attempt to Islamize this theory and to prove it through religious stories. After introducing wisdom, braveness, modesty, and justice, Ghazali introduces some Quran Surah including Asra (Verse 29), Aaraf (verse 31), and Fath (Verse 29) (ibid).

\section{Conclusion:}

Mediocrity is divided into true mediocrity and mediocrity of actions. The virtue is viewed as true mediocrity by Aristotle and Ghazali, which leads to the practical wisdom. The practical wisdom possessor always concentrates on mediocrity, can precisely identify it in varied minor cases, and chooses a properly moderate behavior without any extremes. It is a sensual perfection, which is created in humans as a subsidiary nature. The justice as the virtue of the soul is the real concept of the mediocrity and is the inclusive of all virtues, whose impacts upon the society's transactions, judgments, and political affairs are observable after it is actualized. Accordingly, no extremity is observed. Aristotle and Ghazali use this virtue and mediocrity of actions interchangeably. Since Aristotle and Ghazali consider the practical wisdom as the mediocrity and introduces the virtue of the justice with such feature, so we can say that the man with the practical wisdom is the person who possesses the master of the justice. Such a man can identify the best and the most moderate recognition in the ethical behaviors without any measurement and thought and this is the way to gain the justice statue. So it can be said that, based on these scholars' view, the practical wisdom is the justice and both of them are considered as the mediocrity and the virtue of the soul.

\section{References:}

Ameri, A.M. (1029). Al-Assad\&al-Saadeh Siratt Ensaniyah. (Mojtaba Minavi/2007). Iran: Tehran University.

Aristotle, M. (1979). Al-akhlagh. (Eshagh Ben Hanin/1990). Kuwait: Vekaleh Matbooaat.

Aristotle (2006). Metaphysic. (Ashraf Ol-din Khorasani/2007). Iran: Hekmat Publication.

Aristotle,1999, TheNicomachean Ethics, Great Books, vol 8

Crisp, Roger, Aristotle and Ancient Virtue Ethics, in REP, vol 9

Fakhr Razi, M. (1964). Al-mabahes Almashraghiyeh. Iran: Bina.

Farabi, M.T. (1992). Al-tanbih Sebil Alsaadeh. Iran: Hekmat Publication.

Foot, Philpa,1978, Virtues and vices, and other essays in Moral Philosophy, Oxford, Black Well.

Ghazali, A.H. (1030). Ahya Ulumuddin. Syria: Dar Ol-fekr.

Ghazali, A.H. (2006). The Prosperity Alchemy. Iran: Culture \& Science Publication.

Griffin J. p, 1998,,happiness,, Encyclopedia of philosophy, by G. E Edward carry. Routledge, London and New yourk, V.4

Hughes, Gerard J,1995, Aristotle on Ethics, ed.by Crane and Wolff, University College London.

Ibn-Sina, A.A. (1939). Al-Rasael. India: Golzar Hosseini.

Ibn Meskavayh, A.A. (1033). Tehzeeb-ulIkhlaq\&Al-Tathir Al- a aragh. Iran: Bidar Publication.

Lawrence, C.B. (1999). The Western Morality Philosophy History. Iran: Imam Khomeini Publication.

Lawranc,C.Beker,1992, Encyclopedia of Ethics, New York@London. 
Macintyre, Alasdair, 1984, After virtue (a study in moral theory), Notre Dame, University of Notre Dame Press.

Macintyre, 1988a, A Short History of Moral philosophy from the Homeric agoe to the twentieth century, second Edition.

Macintyre,1988, Whose Justics? Which Rationality? Notre Dame, University of Notre Dame.

Motaheri, M. (2007). Works, Volume I. Iran: Sadra Publication.

Nosbam, M. (1995). Aristotle. (Fooladvand/ 1996). Iran: Tarhe No. Plato, Republic, in Great Books, vol 6

Raphael, D.D, 1971, A Theory of Justice, Cambridge Harvard University Press.

Roos, David, 1991, Aristotle, Revised by: J.L. Ackrill and J.O urmson. New York, oxford University Press.

Seyyed Ghorayshi, M. (2011). A Response to Criticisms against Aristotle's Mediocrity based on the explanation of this theory. The Religious Thought, Shiraz University, N. 38

Shahriyari, H. (2006). Morality Philosophy: The Western Viewpoint of Macintyre. Iran: SAMT Publication.

Sherif, Mohamed, Ahmed, 1975, Ghazalis Theory of Virtue, State University of New York Press.

Shirazi, M.E. (1981). Al Hekma Al-motalee Felasphar Al-arabee Al-aghliye. Lebanon: Darolahya Altaras Arabi.

Tabatabaee, M.H. (2012). Al-mizan in Quaran Interpretation. Lebanon: Aalami. 